\title{
Economic Barriers and Determinants of Employment Rate Changes in the Eastern Wielkopolska Region
}

\author{
Błażej Balewski \\ Higher School of Personnel Management in Konin, Konin, Poland
}

\begin{abstract}
The desire to know the determinants and barriers of development of employment was the main objective of "The Eastern Wielkopolska Labor Market Observations". The mentioned project was financed by European Social Fund. Its executives were the Higher School of Personnel Management together with Konin Chamber of Commerce. The participants of the project were employees and their employers. In the first stage of the program, the participants were the employers who benefited from social financial support, including, at least one of the active unemployment counteraction policy. Salesmen and entrepreneurs in construction industry were mainly represented in this research, because this kind of economic activity is the most popular in the Eastern Wielkopolska Region. The research allowed us to determine some of the main groups of factors that determine the development employment in the future. The study also revealed barriers to such development. Barriers discovered during the project are economic and non-economic factors.
\end{abstract}

Keywords: employment policy, the labour market, economic barriers and determinants of employment, workforce development

The goal of the research conducted as a part of the project concerning observation of the Eastern Wielkopolska labour market was to indicate the factors bringing about beneficial labour demand changes in the Konin subregion. One of the methods to achieve the primary project goal was establishing economic barriers and determinants of short- and long-term employment changes.

\section{Public Support System Characteristics-The Criteria of Participant Selection in the First Part of Research Project}

Since unemployment is determined by economic factors, one of the groups studied in both fundamental stages of the Eastern Wielkopolska labour market observation project were entrepreneurs. The basic step that decided about the choice of the sample from the entrepreneur population in both research stages was to establish the key enterprises. In the first research stage, the key companies for the local market were assumed to be those which had a demand for non-subsidised labour. In the second stage, the key companies for the Eastern Wielkopolska were defined as those which availed of state aid owing to the labour demand which they were generating.

Nowadays, in literature, state aid is defined as: "selective provision of financial benefits to an entrepreneur, which has to equal placing a burden on the public finance" (Choroszczak \& Mikulec, 2009). Such a provision

Corresponding author: Błażej Balewski, Ph.D., Dean of Economic Faculty, Higher School of Personnel Management in Konin, Konin, Poland; research field: HRM effectiveness. E-mail: blazej@balewski.pl. 
can take the form of disbursing funds which apply to the entrepreneur or through decreasing the entrepreneur's benefits in favour of the public finance (Choroszczak \& Mikulec, 2009). It is also important to know what the source of state aid funds is, whether those funds come from the state, and who provides the support (Postula \& Werner, 2006).

The support offers direct or indirect economic profits, also offers financial profits to the supported entities, which are beneficial and privileged when contrasted with the ordinary market conditions of conducting business (Jaźwinski, 2007).

The next, the main feature of state aid is its selective character where some chosen companies are supported at the expense of other companies in the same sector. Thus, the state aid deforms the rules of market competition (Gotz, 2000).

However, state aid is not able to permanently exclude competition since its task is to strengthen the present position of some companies in order to solve their current problems.

The beneficiaries of such help are private and public companies, independent of their business activity type.

\section{The Employment Policy as a Form of the Public Support}

State aid for companies in the labour market is a part of employment policy (see Table 1) and agenda pursued by the state.

Table 1

Chosen Approaches to Employment Policy

\begin{tabular}{|c|c|}
\hline Author & Character and functions of employment policy \\
\hline B. Winiarski & $\begin{array}{l}\text { "(...) state authorities actively influence the labour market, taking into consideration the needs of the } \\
\text { country's economy and reconciling the interests of employers and workers". }\end{array}$ \\
\hline K. Markowski & $\begin{array}{l}\text { "(...) employment policy, as a connection of economic and social policy elements, consists in } \\
\text { developing and implementing employment programmes with some major goals concerning } \\
\text { development of the state economy". }\end{array}$ \\
\hline Z. Wiśniewski & $\begin{array}{l}\text { "(...) sign of activities aimed at rational allocation of human resources }(\ldots) \text { ". "(...) that the main goal of } \\
\text { employment policy is maintaining an unemployment rate that the society would be able to accept (...)". }\end{array}$ \\
\hline M. Kabaj & $\begin{array}{l}\text { The aims of employment policy (policy counteracting unemployment) are to alleviate the financial } \\
\text { burden of unemployment, periodically activate the unemployed with the means of active forms of } \\
\text { employment promotion (as an integral element of socio-economic policy) and analyse and eliminate the } \\
\text { factors that generate unemployment. }\end{array}$ \\
\hline J. Gogolewska & Employment policy serves social and economic functions. \\
\hline W. Jarmołowicz & $\begin{array}{l}\text { "(...) employment policy should have a local character and it is not equal to labour market policy. } \\
\text { Employment policy is mostly aimed at maintaining the existing jobs and creating new jobs on the } \\
\text { so-called primary market whereas labour market policy is a part of employment policy which } \\
\text { concentrates on solving structural and social problems in the already existing labour market". }\end{array}$ \\
\hline
\end{tabular}

Note. Source: Balewski (2014).

As in the situation when there is a problem with defining the range and significance of employment policy, there exist some difficulties with defining in a straightforward way what its goals are. M. Kabaj (1996) states that the most important goal of employment policy, which he also calls policy counteracting unemployment, is to alleviate the financial burden of unemployment, temporarily activate the unemployed with the means of the active forms of employment promotion (as an integral element of socio-economic policy) and analyse and eliminate the factors that generate unemployment (Kabaj, 1996). 
When it comes to influencing unemployment, Z. Wiśniewski (1994) adds that "the main goal of employment policy is maintaining the level of unemployment that can be accepted by the society" (Wiśniewski, 1994).

On the other hand, J. Gogolewska (2001) systemizes the employment policy functions dividing them into social and economic functions (Gogolewska, 2001).

W. Jarmołowicz and M. Knapińska (2005) additionally underline that there is a necessity to provide this policy with a regional character (Jarmołowicz \& Knapińska, 2005).

Employment policy is not equal to labour market policy, for example, because of methods in which they attain their goals. Employment policy is mostly aimed at maintaining the existing jobs and creating new jobs on the so-called primary market, whereas labour market policy is a part of employment policy which concentrates on solving structural and social problems in the already existing labour market (Jarmołowicz \& Knapińska, 2005).

\section{The Active and Passive Role of the Labour Market as a Form of the Employment Policy Implementation}

In terms of its economic dimension, labour market policy can be divided into passive and active policy (Jarmołowicz \& Knapińska, 2005). The first type is characterised by legislative procedures carried out in order to create a cohesive labour law: the so-called autonomous regulators. These are the mechanisms which influence the situation on the labour market without the necessity to make separate decisions each time they are needed, for example, specifying the limit of overtime (Kryńska, Kwiatkowski, \& Zarychta, 1998).

The regulators are also employment benefits, early retirement allowance, early retirement benefits, temporary and designated benefits, payments in kind, severance payments, and other social benefits. These mechanisms mainly serve protective and social functions (Jarmołowicz \& Knapińska, 2005).

The second type of policy, apart from legislation, consists in direct actions undertaken by the authorities on the labour market through developing and implementing non-autonomous regulators (mechanisms that require a separate decision of the authorities each time they are needed) (Krajewska, 2003).

These mechanisms are "a set of instruments whose task is to introduce the unemployed into the labour market" (Golinowska, 2001). Usually, the active labour market policy is aimed at activating the unemployed from the so-called high-risk group.

In the transitional market theory, labour market policy is called "proactive policy", which is aimed at cooperation and promoting equal opportunities on the labour market. Active labour market policy also supports the transition between: part-time and full-time employment, population of the unemployed and the employed (Meager, 1998), and from the education system to the labour market (Maksim, 2005).

In Poland, at the time of implementation of the project, the active state policy instruments (see Figure 1) whose goal is to introduce the unemployed to the labour market and stimulate individual professional activity are as follows:

(1) Intervention jobs, i.e., employing a jobless person as a result of an agreement with the district governor, which is to support those people whose situation on the labour market is special, for example, they are below 25 or over 50 years of age, they have been unemployed for a long time, they do not have any professional qualifications, raise at least one child at the age of seven or less on their own, or are unemployed and disabled [Article 2 (26) and Article 49 of Act on Promotion of Employment an Labour Market Instruments, Dz.U. 
(Journal of Laws), 2004, No. 99, Item 1001]. According to the legal definition, intervention jobs are those where the jobless are employed in a company which is not undergoing liquidation and has not reduced the number of employees by more than $10 \%$ in the last six months. Such employment cannot last longer than 12 months and is based on a contract signed previously with the district employment office [Article 31 §2 (18) of the Act on Employment and Counteracting Unemployment, 1995 Dz.U. (Journal of Laws), No. 1, Item 1, as amended];

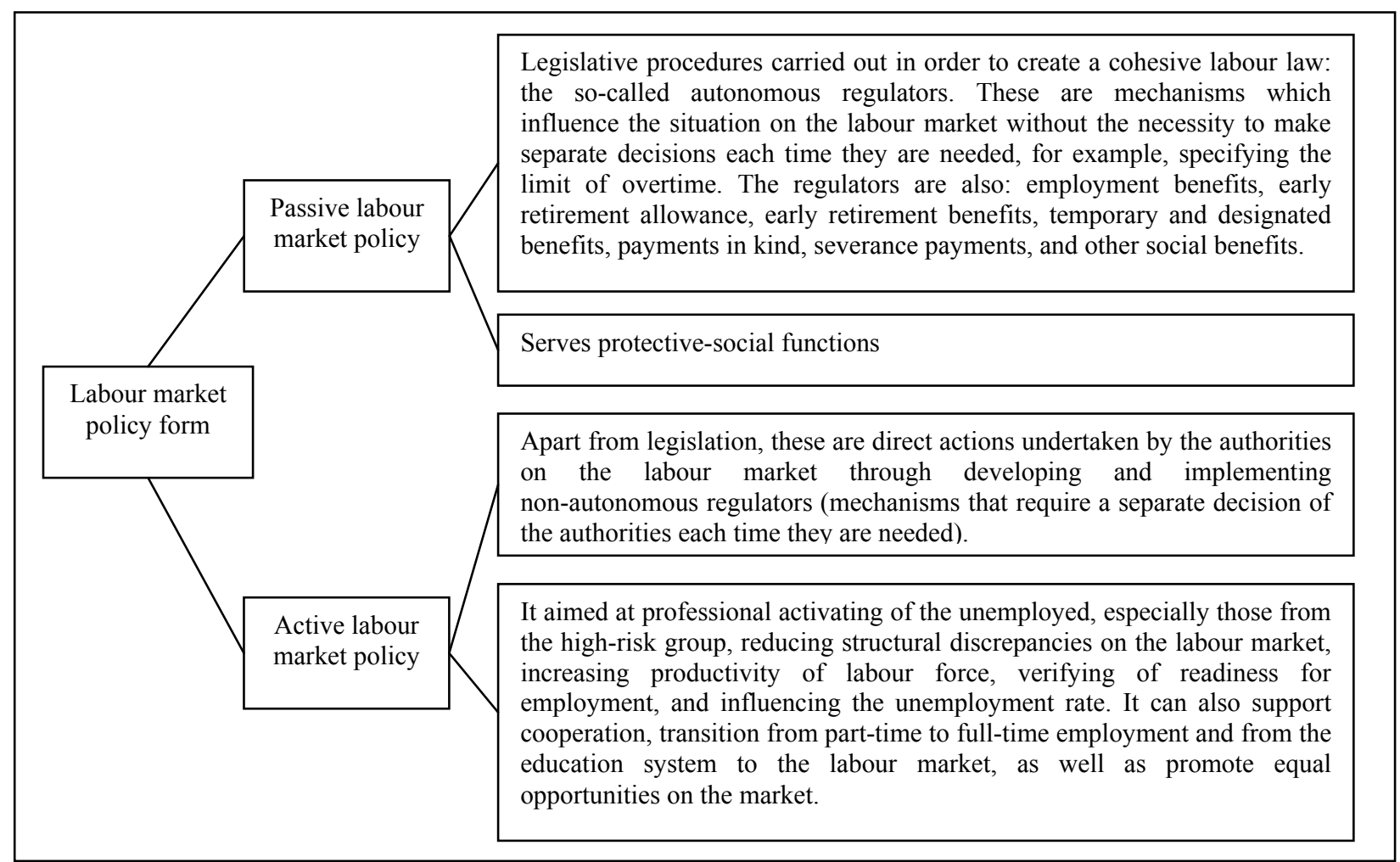

Figure 1. Characteristics of labour market policy forms. Source: Balewski (2014).

(2) Public works, i.e., employing a jobless person for less than 12 months at the works aimed at vocational and social reintegration, defined pursuant to the provisions on community employment, organized by social welfare centres or non-government organizations dealing, according to their statuses, with issues related to environment protection, culture, education, sport and tourism, health care, unemployment and social welfare, as well as waterway companies and their associations if the works are financed or co-financed from the means of territorial self-governments, the state budget, target funds, NGOs (non-governmental organizations), waterway companies or their associations [Article 2 (32) of the Act on Promotion of Employment and Labour Market Instruments, Dz.U. (Journal of Laws), 2004, No. 99, Item 1001]. The previous legislative act defined public works as employing a jobless person for less than 12 months at the works organized by territorial self-governments, social welfare centres, or non-government organizations dealing, according to their statuses, with issues related to environment protection, culture, education, sport and tourism, health care, unemployment and social welfare, as well as waterway companies and their associations if the works are financed or co-financed from the means of territorial self-governments, the state budget, target funds, by NGOs, waterway companies or their associations [Article 2 (21) of the Act on Employment and Counteracting Unemployment, 1995 Dz.U. (Journal of Laws) No. 1, Item 1, as amended]; 
(3) Educational classes outside school aimed at obtaining and developing vocational and general skills and qualifications including the skills of seeking employment [Article 2 (37) of the Act on Promotion of Employment and Labour Market Instruments, Dz.U. (Journal of Laws), 2004, No. 99, Item 1001]. The previous legislative act defined training as: vocational training, retraining, developing professional qualifications, and acquiring skills helpful in seeking and getting a job [Article 2 (22) of the Act on Employment and Counteracting Unemployment, 1995 Dz.U. (Journal of Laws), No. 1, Item 1, as amended];

(4) Labour market instruments supporting the basic labour market services. These are, among others, internships and trainings organised in the workplace, covering transport costs for an employee if an employer has reported vacancies, financing accommodation in a workplace, co-financing equipment, legal consulting and counselling, reimbursing the costs of social contributions, participation in creating company training funds, etc. [Article 44, 45, 46, 53, and 68 of the Act on Promotion of Employment and Labour Market Instruments, Dz.U. (Journal of Laws), 2004, No. 99, Item 1001]. According to the previous legislative act, special programmes consist in activities aimed at employment promotion, initiated by employment authorities for people who belong to the risk group on the local labour markets [Article 2 (19) of the Act on Employment and Counteracting Unemployment, 1995 Dz.U. (Journal of Laws), No. 1, Item 1, as amended];

(5) Granting loans from the labour fund:

(a) To companies to organise additional jobs for the unemployed who will be referred to those jobs (Granting a loan is dependent on the following conditions: The company has not reduced employment in the last 12 months, it did not avail of the loan before or, if it has used some form of subsidising employment, the company has to make its activities credible to the labour fund administrators);

(b) To unemployed reserve soldiers seeking employment, who are working out their notices of termination of a contract, whose employer has declared bankruptcy, who receive a welfare benefit granted to persons on miner's leave, participate in individual integration programmes, referred to in the provisions on social welfare, aimed at financing training costs [Articles 42 and 43 of the Act on Promotion of Employment and Labour Market Instruments, Dz.U. (Journal of Laws), 2004, No 99, Item 1001]. The previous definition stated that a loan can be granted to the unemployed seeking employment when they are working out their notices of termination of a contract for reasons related to the work place, receive a welfare benefit granted to persons on miner's leave or a miner's welfare allowance in order for the loaner to start a non-agricultural or agricultural business, except for the purchase of a land [Article 18 (1), points 1 and 2 of the Act on Employment and Counteracting Unemployment, 1995 Dz.U. (Journal of Laws), No. 1, Item 1, as amended].

In the global economy, the influence of the state on the labour market is not a new phenomenon although, in the last decades, it has undergone significant changes (Markowski, 1992). However, in literature, we can encounter opinions that increasing direct state influence on the labour market and workforce development caused problems with combating the rising unemployment with traditional global demand stimulation tools, limited the possibilities to use expansive fiscal and financial instruments when inflationary pressure was very high, and an increased influence of technological and structural factors on the unemployment (Markowski, 1992).

Nevertheless, the policy of intervention was used in practice by the states facing crises. This surely stems from the nature of a state, which safeguards social values and creates conditions for using and enriching those values (Zwoliński, 1990). 


\section{The Characteristics of the Research Sample in the First Part of the Project Implementation}

Many entrepreneurs in the Eastern Wielkopolska take advantage of this function of the state in the real life, especially those of them who own micro and small enterprises. Out of this group, representatives of 111 micro-enterprises were invited to take part in the project (50.5\% of the sample), which employ no more than nine full-time employees (see Figure 2).

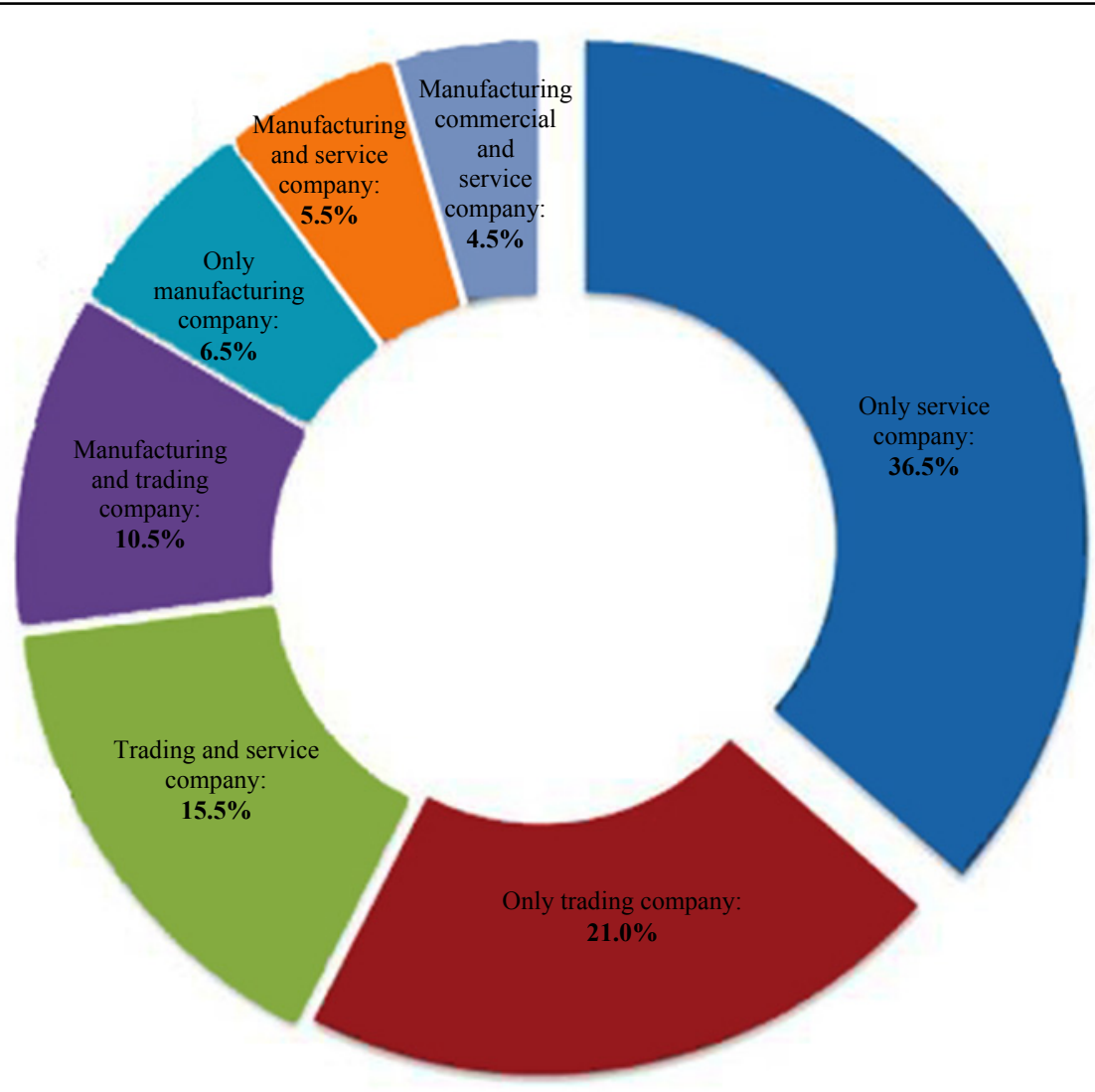

Figure 2. Character of the conducted activity. Source: the author's own research "The Eastern Wielkopolska Labour Market Observations".

Among them, 21.5\% employed one person, $19.5 \%$ employed two to five (2-5) people, and $9.5 \%$ employed six to nine (6-9) people. Moreover, 57 small enterprises which employed 10-49 people took part in the research. They constituted $28.5 \%$ of the research sample.

The remaining 32 companies were medium enterprises which employed 50-249 people (19.5\% of the sample) and large enterprises which employed more than 249 people ( $1.5 \%$ of the sample).

When it comes to the business structure, the largest group (36.5\%) were entities offered exclusive services. The second largest group were trading companies, constituting $21 \%$ of the sample.

Trading and service companies constituted $15.5 \%$ of the sample and manufacturing and trading companies constituted $10.5 \%$ of the sample.

The largest group of companies (40.5\%) came from economic Sector G (wholesale and retail trade: repair of motor vehicles and motorcycles). Therefore, they dealt with retail and wholesale trade. Then, 20.5\% of the companies came from Sector C (manufacturing), 18.5\% from Sector S (other service activities). 
Sector F (construction) was represented by $11.5 \%$ of the studied companies. The other economy sectors were represented by less than $10 \%$ of the studied companies (see Table 2).

Table 2

Percentage of Companies From the Selected Economic Sectors (\%)

\begin{tabular}{ll}
\hline Economic sectors & Percent (\%) \\
\hline G-wholesale and retail trade: repair of motor vehicles and motorcycles & 40.5 \\
C-manufacturing & 20.5 \\
S-other service activities & 18.5 \\
F-construction & 11.5 \\
H-transportation and storage & 5.5 \\
P-education & 4.5 \\
K-financial and insurance activities & 4.0 \\
Q-human health and social work activities & 3.0 \\
A-agriculture, forestry, and fishing & 2.5 \\
I-accommodation and food service activities & 2.5 \\
N-administrative and support service activities & 2.5 \\
E-water supply: sewerage, waste management, and remediation activities & 2.0 \\
O-public administration and defence: compulsory social security & 2.0 \\
R-arts, entertainment, and recreation & 2.0 \\
M-professional, scientific, and technical activities & 1.0 \\
D-electricity, gas, steam, and air conditioning supply & 0.5 \\
J-information and communication & 0.5 \\
Total & 100.0 \\
\hline
\end{tabular}

Note. Source: the author's own research "The Eastern Wielkopolska Labour Market Observations".

The structure of the sample may seem to deform the real image. However, the sample has been gathered reliably since it selected companies on the basis of their main business activity type. This allowed us to avoid false multiplication of data, which would take place if we showed the same entrepreneur many times if he or she declared conducting business activities in more than one group, class, or subclass of the Polish Classification of Activity (see Table 3).

Table 3

The Number of Sector G Companies in the City of Stupca

\begin{tabular}{lll}
\hline Class & Group name & $\begin{array}{l}\text { Active as of } \\
\text { December 31, 2011 }\end{array}$ \\
\hline $42.11 \mathrm{Z}$ & Works related to construction of roads and motorways & 29 \\
$42.12 \mathrm{Z}$ & Works related to construction of railways and underground railways & 0 \\
$42.13 \mathrm{Z}$ & Works related to construction of bridges and tunnels & 3 \\
$42.21 \mathrm{Z}$ & Works related to construction of transmission pipelines and distribution networks & 6 \\
$42.22 \mathrm{Z}$ & Works related to construction of telecommunications and electricity lines & 8 \\
$42.91 \mathrm{Z}$ & Works related to construction of water projects & 3 \\
$42.99 \mathrm{Z}$ & Works related to construction of other civil engineering projects not elsewhere classified & 11 \\
$43.11 \mathrm{Z}$ & Demolition & 58 \\
$43.12 \mathrm{Z}$ & Site preparation & 59 \\
$43.13 \mathrm{Z}$ & Test drilling and boring & 5 \\
$43.21 \mathrm{Z}$ & Electrical installation & 63 \\
$43.22 \mathrm{Z}$ & Plumbing, heat, and air-conditioning installation & 54 \\
\hline
\end{tabular}


Table 3 continued

\begin{tabular}{lll}
\hline Class & Group name & $\begin{array}{l}\text { Active as of } \\
\text { December 31, 2011 }\end{array}$ \\
\hline $43.29 Z$ & Other construction installation & 79 \\
$43.31 Z$ & Plastering & 95 \\
$43.32 Z$ & Joinery installation & 103 \\
$43.33 Z$ & Floor and wall covering & 116 \\
$43.34 Z$ & Painting and glazing & 116 \\
$43.39 Z$ & Other building completion and finishing works & 122 \\
$43.91 Z$ & Roofing activities & 59 \\
$43.99 Z$ & Other specialised construction activities not elsewhere classified & 100 \\
Total & & 973 \\
\hline
\end{tabular}

Note. Source: Kałecki (2012).

\section{The Main Determinants of the First Research Stage in "The Eastern Wielkopolska Labor Market Observations" Implementation}

Multiplication, usually serving short-term populist goals, takes place when, for example, among all 1,444 companies, carrying out activities in a given city as of December 31,2011, 67.3\% are Sector G enterprises, and at the same time, 158 of them are Sector H enterprises, 31 of them are Sector I enterprises, 181 of them are Sector K enterprises, and 451 of them are Sector $\mathrm{N}$ enterprises (in total, many more than the general number of enterprises in the area).

In the image of reality demonstrated by the sample and its choice, only the change in the number of active enterprises during both research stages is not reflected (see Table 4).

Table 4

Entrepreneurs Entered in the Business Activity Register of the City of Stupca

\begin{tabular}{llllll}
\hline Years & $\begin{array}{l}\text { Total number } \\
\text { registered }\end{array}$ & Newly registered & Deregistered & $\begin{array}{l}\text { Changes in register } \\
\text { entries }\end{array}$ & Currently operating \\
\hline 2009 & 4,320 & 160 & 146 & 180 & 1,402 \\
2010 & 4,461 & 141 & 111 & 349 & 1,432 \\
2011 & 4,563 & 102 & 90 & 216 & 1,444 \\
\hline
\end{tabular}

Note. Source: Kałecki (2012).

This is a result of the general project assumptions and, due to a small scale of quantitative changes, does not influence the research results.

Among the most important conclusions which are drawn from both research stages, the most important one concerns very small labour demand.

Only $17.5 \%$ of the studied companies are planning to employ more people. The largest number of companies (64\%) is planning to keep the number of employees at the same level, whereas a drop in the number of employees is predicted by $8.5 \%$ of the studied entities. Every 10th entrepreneur in the research could not specify whether the number of company employees would increase or decrease and answered "I don't know".

Such a structure of answers doubtlessly indicates that there are numerous obstacles in the socio-economic reality that make it difficult to increase employment on the local labour market.

Nearly two-thirds of the studied companies indicated high labour costs, i.e., the so-called tax wedge as the main barrier in increasing the employment. The higher the wedge, the more expensive employing new workers 
becomes. Consequently, employers limit the number of employees and those who want to take up a new job remain jobless. A high tax wedge encourages employers to hide their profits and hire people illegally (Bogdańska, 2012), thus contributing to the creation of the grey zone. In 1995, the Central Statistical Office initiated a yearly research on the grey zone, the unregistered, i.e., illegal labour. The research has shown that the number of employees who admitted to be working in the grey zone is systematically dropping. In 1995, the number was 2.2 million employees, in 1998, the number was 1.43 million, in 2004, the number was 1.31 million, and in 2009 , it was only 785,000 , which constitutes $4.6 \%$ of the working population. However, this change in the size of the grey zone does not derive from lowering the tax wedge, but from the fact that the European labour market opened for Poles, which has brought about demographic changes concerning the working population of Poles (Margalus, 2012).

It can be added that the same effect is caused by a factor that was not mentioned by the respondents: a high minimum wage (Wojciechowski, 2008).

The respondents also indicate that the labour demand stagnation determinants can be divided into three groups. The first one is a group of elements connected to the human capital quality in the group of the unemployed. These are the following elements (see Figure 3):

(1) A restricted number of employees who have certain qualifications ( $22 \%$ of the answers);

(2) High social benefits (11.5\% of employers);

(3) Unreasonable demands of the future employees (10.5\% of employers);

(4) Employees' unwillingness to work (4.0\%) or to work overtime (3.5\%).

I don't know: $10.0 \%$

We're planning to increase the number of employees: $17.5 \%$

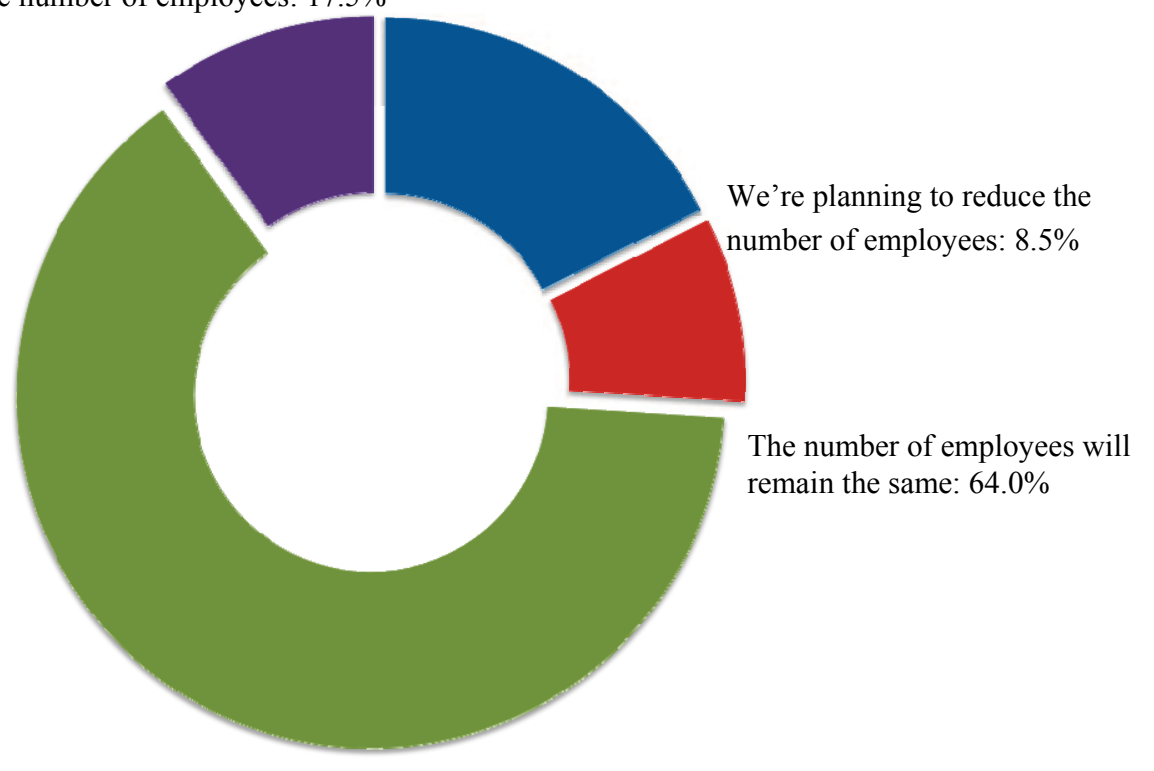

Figure 3. The planned changes in employment of permanent employees in the next 12 months. Source: the author's own research "The Eastern Wielkopolska Labour Market Observations".

These elements are undergoing systematic changes, for example, owing to the implementation of Operational Programme Human Capital projects. However, one can unfortunately expect that their value will 
be influenced by the so-called intergenerational value transmission.

The second group of factors is connected to a company's macro environment, mainly the uncertainty as to the company's future or the general economic situation (mentioned by one in five respondents). This is the group of stagnation determinants which is dependent on the activities of the local labour market institutions to the least extent. Changes in this area take place due to changes in the global economy (see Figure 4).

High labour costs (social insurance, taxes, etc.)
No funds
Difficulties in finding an employee with the
desired qualifications
Uncertainty as to the company's future
Uncertainty as to the general economic situation
No orders
Major social benefits
No demand for the company's own products
Too high expectations from potential employes
Unwillingness of potential employees to work
No such barriers
General unwillingness of potential employees
to work overtime

Figure 4. Barriers restricting the possibility to employ in accordance with the entity's needs. Source: the author's own research "The Eastern Wielkopolska Labour Market Observations".

The third group consists of elements connected to company marketing and management. Barriers mentioned by the respondents were, for example, lack of orders (15.5\%) or lack of demand for the company's own products $(11 \%)$. Such information was provided by one in 10 respondents, which indicates that the local economy is not very competitive. Therefore, qualitative modification of the elements that create this market force should be aimed at, for example:

(1) Architecture, internal and external company relations defining the relationship between the company and its employees, suppliers, clients, and competitors;

(2) Reputation, the client's opinion of the company;

(3) Innovation: new products, technologies, and management ideas produced by the company;

(4) Strategic resources resulting from the previously incurred costs, natural monopoly, and access to the protected resources.

Unfortunately, only $4.0 \%$ of the respondents do not experience any barriers which would deter them from employing new workers. Therefore, the analysis of employment growth determinants which were indicated by the respondents was presented with the utmost caution. Already at the stage of formulating conclusions, there is an indication of a need to constantly falsify them. 
The reasons for employment growth indicated by the respondents can be varied.

The main reason for employment is a growth in the number of products and services provided by a company (see Figure 5). The fact that local entrepreneurs mentioned such an employment growth factor demonstrates that they intuitively understand the economic law which states that labour demand is a secondary demand, dependent on the demand for goods, whose production requires human labour.

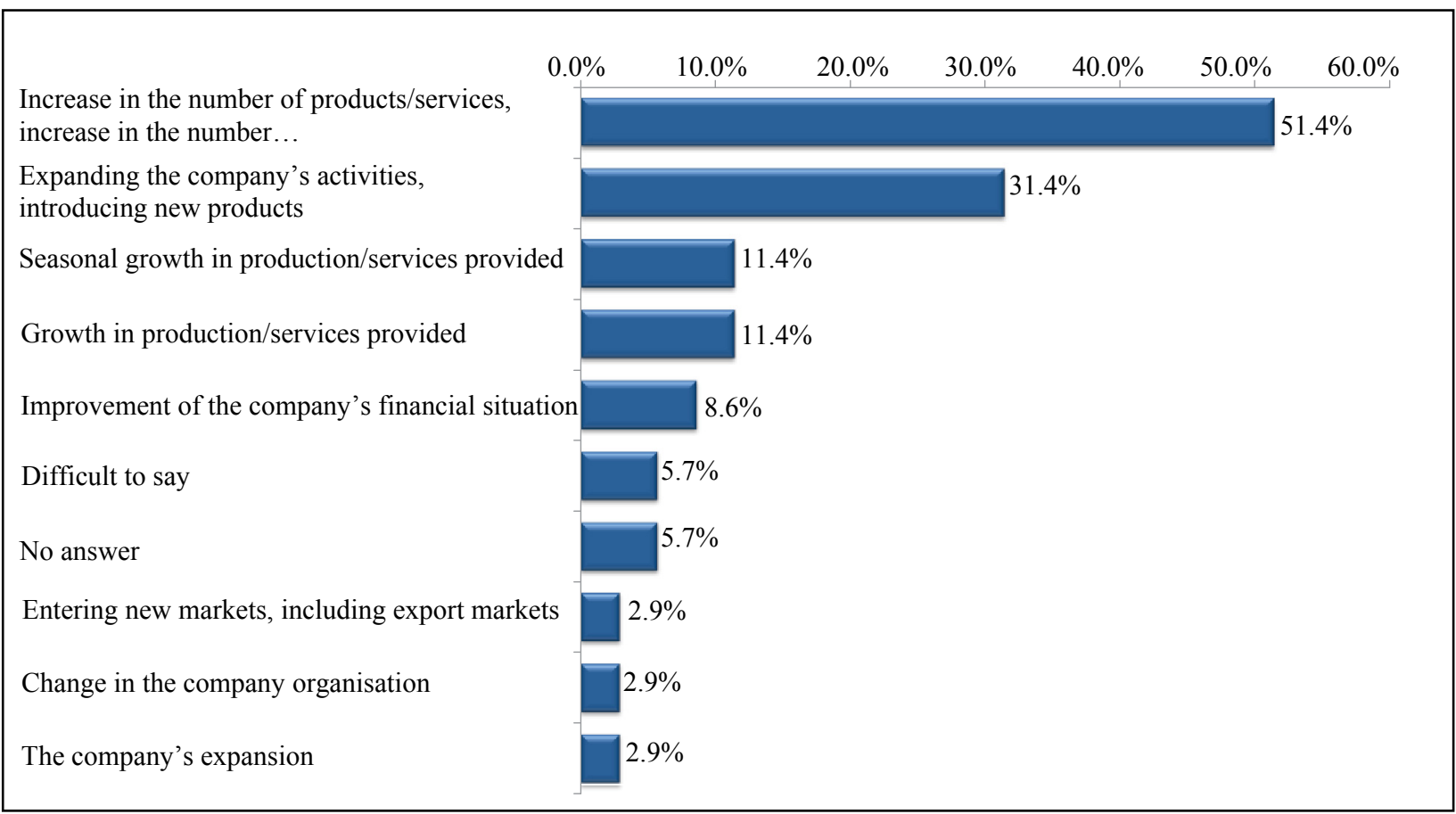

Figure 5. Reasons for the planned increase in the number of employees in the next 12 months. Source: The author's own research "The Eastern Wielkopolska Labour Market Observations".

For the local market, including the labour market, to develop further, it seems to be important that six entrepreneurs mentioned that a change in the company's organisation has influenced the number of its employees. If organisational changes contribute to a growth at the negentropy level, then this employment growth seems to be rather stable and sustainable.

\section{References}

Balewski, B. (2014). Effective unemployment counteraction as a determinant of national security. Journal of US-China Public Administration, 11(11), 109.

Bogdańska, A. (2012). Przeciwdziałanie bezrobociu wśród mieszkańców miasta Słupcy w wieku od 18 do 25 lat (Counteracting unemployment in the city of Słupca among citizens between 18 and 25 years of age). Unpublished B.A. thesis, Faculty of Economics and Management, School of Management in Konin.

Choroszczak, J., \& Mikulec, M. (2009). Pomoc publiczna a rozwój firmy: szanse i zagrożenia (State aid and company development: Opportunities and dangers). In S. Najdzińska (Ed.), System pomocy publicznej dla matych i średnich przedsiębiorstw w Polsce (State aid system for SMEs in Poland). Unpublished B.A. thesis, Faculty of Economics and Management, School of Management in Konin, Konin.

Gogolewska, J. (2001). Regulowanie rynku pracy (Regulating labour market). In B. Winiarski (Ed.), Polityka gospodarcza (Economic policy) (p. 467). Warsaw: PWN.

Golinowska, S. (2001). O przyczynach bezrobocia i polityce jego zwalczania (About the causes of unemployment and the policy of counteracting them). Social Policy, 3, 16. 
Gotz, V. (2000). Subsidy law. In M. Sausesa (Ed.), Economic law. Warsaw: Publishing House C.H. Beck.

Jarmołowicz, W., \& Knapińska, M. (2005). Polityka państwa na rynku pracy... (State policy on the labour market...) (p. 91, p. 163). Poznań.

Jaźwinski, I. (2007). State aid for companies, entrepreneurship, innovation knowledge-based economy. Zeszyt Naukowy Scientific Notebook (The Scientific Issue Scientific Notebook), 453.

Kabaj, M. (1996). Effectiveness of macroeconomic programmes counteracting unemployment. In M. Bednarski, Active forms of counteracting unemployment. Instruments and institutions (p. 310). Warsaw: Institute of Labour and Social Studies.

Kałecki, M. (2012). Rozwój usług w powiecie słupeckim w latach 1989-2011 (Services development in the Słupca District in the years 1989-2011). Unpublished B.A. thesis, Faculty of Economics and Management, School of Management in Konin.

Kryńska, E., Kwiatkowski, E., \& Zarychta, H. (Eds.). (1998). Polityka państwa na rynku pracy w latach dziewięćdziesiatych (State policy on the labour market in the 1990s) (pp. 125-126). Warsaw: IpiSS.

Maksim, M. (2005). Aktywna polityka rynku pracy w krajach Unii Europejskiej. Ewolucja koncepcji: instrumenty i finansowanie (Active labour market policy in the member states. Evolution of the concept: Instruments and financing). In A. Pocztowski (Ed.), Praca i zarzadzanie kapitałem ludzkim w perspektywie europejskiej (Labour and human resources management in the European perspective) (p. 163). Kraków: Oficyna Ekonomiczna (Economic Publishing House).

Margalus, M. (2012). Przeciwdziałanie bezrobociu na przykładzie Powiatowego Urzędu Pracy w Słupcy (Counteracting unemployment: Example of the District Employment Office in Słupca). Unpublished B.A. thesis, Faculty of Economics and Management, School of Management in Konin.

Markowski, K. (1992). Rola państwa w gospodarce rynkowej (The role of the state in the market economy) (p. 154). Warsaw: PWE.

Meager, N. (1998). Transitional labour markets: Bridges between dependent and self employment. In H. Schwedler (Ed.), New institutional arrangements in the labour market: Transitional labour markets as a new full employment concept. Berlin: European Academy of the Urban Environment.

Postula, I., \& Werner, A. (2006). Pomoc publiczna (State aid). In S. Najdzińska (Ed.), System pomocy publicznej dla matych $i$ średnich przedsiębiorstw w Polsce (State aid system for SMEs in Poland). Unpublished B.A. thesis, Faculty of Economics and Management, School of Management in Konin, Konin.

Wiśniewski, Z. (1994). Polityka zatrudnienia i rynku pracy w RFN (Employment and labour market policy in the Federal Republic of Germany) (p. 31). Toruń: UMK.

Wojciechowski, W. (2008). Where does the unemployment come from. In A. Bogdańska (ed.), Counteracting unemployment in the city of Stupca among citizens between 18 and 25 years of age. Unpublished B.A. thesis, Faculty of Economics and Management, Higher School of Personnel Management in Konin.

Zwoliński, A. (2005). Wprowadzenie do rozważań o narodzie (Introduction to considerations about the nation). Kraków: WAM Publishing House. 